Przegląd Narodowościowy / Review of Nationalities • nr 9/2019 - Sports as the expression of nation issues

sciendo

ISSN 2084-848X (print) • ISSN 2543-9391 (on-line) • DOI 10.2478/pn-2019-0022

\author{
Marcin Pisarski* \\ University of Zielona Góra, Zielona Góra, Poland \\ https://orcid.org/0000-0002-3714-7036
}

\title{
Przedhitlerowskie korzenie nazizmu, czyli dusza niemiecka w świetle filozofii i religioznawstwa, Scientific Editorial Board Bogumił Grott, Olgierd Grott, Warsaw 2018
}

In 2018, the von Borowiecky publishing house published a collection of texts edited by Bogumił Grott and Olgierd Grott titled Przedhitlerowskie korzenie nazizmu, czyli dusza niemiecka $w$ świetle filozofii i religioznawstwa (Eng. Pre-Hitlerian Roots of Nazism, or German Soul in the Light of Philosophy and Religious Studies). The publication included texts by outstanding Polish academics - Bogdan Suchodolski and Leon Halban - which were reprinted years later. Suchodolski's text titled Dusza niemiecka $w$ świetle filozofii (Eng. The German Soul in the Light of Philosophy) was published in 1945 and then in 1947. Halban's works also come from the first years after the end of the World War II. Mistyczne podstawy narodowego socjalizmu (Eng. The Mystical Basics of National Socialism) were published twice - in 1946 and 1948, while Religia starogermańska i jej aktualne znaczenie w Niemczech (Eng. The Old German Religion and its current significance in Germany) in 1949. Professor Suchodolski - described as one of the most outstanding Polish humanists - was a historian, philosopher, pedagogue and theoretician of education. From 1938, he was the Head of the Department of Pedagogy at the Jan Kazimierz University in Lvov, and from the end of the war until his retirement he was the Head of the Department of Pedagogy at the University of Warsaw (Przedhitlerowskie korzenie nazizmu, 2018: 11-12). Halban from the beginning of his career was associated with the Jan Kazimierz University in Lvov, where in 1916 he received his doctoral degree, in 1926 he habilitated in the field of canon law, and in 1932 he received the title of professor. Halban specialized in canonical law, gradually expanding his scientific interests to include religious studies. Today, he is sometimes referred to as a "pioneer in the political science of religion" (Przedhitlerowskie..., 2018: 12-13).

Bogumił Grott and Olgierd Grott are both the editors and authors of an extensive introduction to Przedhitlerowskie korzenie nazizmu. They are researchers known for their numerous publications on the interaction between religion and politics ${ }^{1}$. Profes-

${ }^{1}$ In the context of Przedhitlerowskie korzenie nazizmu, their collective work Wiedza religioznawcza w badaniach politologicznych (2015), is worth mentioning.

* Correspondence address: Instytut Nauk o Polityce i Administracji, Uniwersytet Zielonogórski, Al. Wojska Polskiego 69, 65-762 Zielona Góra, Polska, e-mail: pisarskimarcin@wp.pl. 
sor Bogumił Grott, often recalling in his books the achievements of Halban, is himself an effective promoter of an interdisciplinary approach to issues related to the political science of religion in the field of Polish science. Olgierd Grott is the author of the book Faszyści i narodowi socjaliści $w$ Polsce, especially interesting in the context of the presented publication, because it presents the effect of transferring national socialist inspirations to the Polish society, characterized by a completely different "axiological situation" than in Germany. In the light of Suchodolski and Halban's findings, the Polish fascist or national socialist groups described by Olgierd Grott were an example of political hybrids, which included foreign fascinations on the one hand, and Catholicism declared by their members on the other (Grott, 2007).

Suchodolski in Dusza niemiecka w świetle filozofi, basing his analysis on the concepts dominating in German philosophy, points out those which, in his opinion, created a specific, unique approach to ethical and religious issues among Germans, compared to other nations. The author emphasizes that the creation of such characteristics is a difficult task, and the experience of the just-completed war might have made it difficult to see objectively, but the search for such an answer is a duty of academics towards the general public. Suchodolski begins his deliberations by pointing out the then universal concept of the duality of German culture, which consists of the so-called Weimar and Potsdam cultures - the nation of poets and philosophers and the nation of soldiers and Prussian discipline. The author expresses the thesis that the culture of Potsdam was characteristic of the next generation of Germans (Przedhitlerowskie..., 2018: 33).

Suchodolski analyses the problem by defining the philosophical line of opposition characteristic of German philosophical thought, specific German negations that do not allow for the implementation of ideas that dominate in most European countries in parallel. As the main lines of the argument, the author points out the opposition to rationalism, empiricism and Christian ethics. Suchodolski points to the issue of a specific understanding of some philosophical concepts or highlighting those elements of particular theories that correspond to the described German soul. In Suchodolski's opinion, the Germans perceived the French Revolutions as an expression of an erroneous approach to socio-political issues, which should not be based on rationalism in the light of German philosophy. I would like to use the term "irrational rationalists", which Suchodolski sees in Karl Marx and Sigmund Freud. "The first one, by the very nature of his disposition to rationalism, stood halfway down that road, being a student of [Georg] Hegel for nothing", from whom he derived a tendency to historical thinking and the recognition of contradictions as a fundamental factor in life; stood in opposition to post-revolutionary utopian socialism, which had no chance of building social harmony based on reason and goodwill. As for Freud, who, under the influence of German philosophy, came to "a complete philosophical system in which human nature was presented as the intertwining of the eternal and irrational struggle between erotic and death drives" 
(Przedhitlerowskie..., 2018: 38). The objection to empiricism was to be based on the Kantian conviction that the existing world is chaos which must be formed by human thought, because "human cognition becomes more perfect than reality". Similarly, in the case of Hegel, Suchodolski quotes his statement that if nature does not want to comply with the laws imposed on it by philosophies, it is even worse for nature itself. In Suchodolski's view, the period from Immanuel Kant to Hegel became fundamental for the formation of German philosophy, influencing almost all currents of German thought in the $19^{\text {th }}$ and $20^{\text {th }}$ centuries (Przedhitlerowskie..., 2018:46). Apart from idealism and historism, or to a lesser extent German existentialism, the formation of political ethics was influenced by a specific understanding of concepts as fundamental as truth and falsehood, or good and evil. In his reflections on concepts fundamental to ethics, Suchodolski refers to the figure of Carl Schmitt and his definition of politics based on conflict, the juxtaposition of friend and enemy. Schmitt treated politics as a peculiar field of human activity, outside of ethical categories.

Suchodolski, being aware that such a position may provoke protests of supporters of German philosophy under the sign of Kant, maintained his position on the leading role in shaping the German thought of philosophers such as Hegel, Johann Fichte and Friedrich Nietzsche. At the same time, he emphasizes the still-present phenomenon of the different reception of thoughts of philosophers such as Kant or even Nietzsche on German and European grounds (Przedhitlerowskie..., 2018: 65).

Mistyczne podstawy narodowego socjalizmu by Halban, as the author himself writes in the introduction to the second edition, encountered a number of accusations that the work touches upon irrational issues that do not fit the materialistic vision of the world. Halban's work, however, bears witness to how important and how touching the real material world was the influence of mystical elements within the framework of differentiated and divided into many trends Protestant theology or among neopagan circles. The philosophical and religious climate of contemporary Germany, apart from the multitude of trends within individual Protestant confessions or the development of neopagan formation, was also characterized by an increase in the popularity of oriental religions. In spite of their irrational character, Halban believed that the described tendencies had a significant influence on science, especially historiosophy, philosophy and extremely diverse Protestant theology (Przedhitlerowskie..., 2018: 83). The axiological situation of Germany at the turn of the $19^{\text {th }}$ and $20^{\text {th }}$ centuries described above leads Halban to the conclusion that it is not the Nazi movement that creates a specific mysticism, but it is itself the result of mystical elements rooted in German culture, operating in the sphere of religious and political myths.

An extreme approach to the science of predisposition led to the creation of a number of concepts that proclaimed the special historical mission of the German nation. From the Christian point of view, this took on the form of heresy, as in the poetry of Angelus 
Silesius led by Halban, or in the works of Master Eckhart, whose special role in shaping German mysticism was recalled by the Nazi ideologist Alfred Rosenberg (Przedhitlerowskie..., 2018: 87). Halban's distinction between religious and mystical experiences became important.

Against the background of a large number of religious groups, theologians or writers referring to Germanic mysticism, Halban assigns a special authority to Paul de Lagarde, a professor of Protestant theology. The work of de Lagarde had a weakening effect on the authority of Holy Scripture, which in turn facilitated interference in Christian ethics and its free formation, in accordance with the needs of the then designed German religion. This was to lead, as Rosenberg emphasized, to a break up with Christian universalism, to the creation of one's own interpretation of Scripture and the person of Jesus, as well as to the recognition of Catholic influences as embarrassing for German ethics. On the basis of "Germanized Christianity", Deutsche Christen organization was the leader, striving to create a non-confessional, common German faith. In addition, a number of neopagan organizations were active and openly hostile to Christianity. What Halban particularly emphasized, a significant part of the Third Reich elite came from organizations operating within the described neopagan trends, or the socalled Germanized Christianity.

The collection closes with a second text by Halban titled Religia starogermańska $i$ jej aktualne znaczenie w Niemczech. While Mistyczne podstawy narodowego socjal$i z m u$ shows the individual directions in which German spirituality followed, moving away from Christian ethics and universalism, in the following text, the author focuses to a greater extent on indicating the force with which the described thought currents, influencing science or literature, shaped the prevailing world view in society. Halban divides his deliberations into five parts, analyzing the influence of specific religiousness on the worldview of the entire German society and questioning the authenticity of the German myths preached in the period in question. Pointing to the existing, at the time of writing, richness of religious issues, which are of interest to researchers, he points to the involvement of many German scientists in the ideas of broadly understood Germanism. As symptomatic in this field, he points to the theories about the alleged equivalence of the ancient culture and religion of the pagan Germans, or even their superiority to the classical Greek and Roman cultures. As a representative of such views, Halban points to the Dutch linguist and researcher of German mythology, Jan de Vries (Przedhitlerowskie..., 2018: 123). Halban emphasizes that in the light of already known scientific findings, even at the level of individual strains, there were significant differences, which calls into question the convictions of many German organizations referring to, for example, the Icelandic Edda. Describing the issue in Staropogańskie elementy duchowe a światopogląd germańskie, Halban emphasizes that the representatives of universalist directions, perceived abroad as proper representatives of German culture, 
were in fact a minority in their country. In Halban's opinion, the true German tradition is not the cultural and civilizational unity of all Germanic peoples, but the natural desire for fragmentation, and the only ideas working towards unification were Christianity and the political concept of the empire, foreign in Germanism terms (Przedhitlerowskie..., 2018: 169).

Halban considered the most visible feature of the German worldview to be the hostility towards Christianity, especially its ethical layer. This was to be seen both among historians and philosophers, and with particular power in the field of literature (Przedhitlerowskie..., 2018: 170). It is not surprising, therefore, that he points to Nietzsche's philosophy as corresponding to the worldview of the majority of Germans, as evidenced by the fact that Nietzsche's arguments against Christianity can be found exceptionally often in German literature (Przedhitlerowskie..., 2018: 174). In the conclusion describing Trwanie elementów wierzeniowych pozachrześcijańskich, he points to the ongoing history of resistance to Christianity imposed by violence, the preservation of old customs or rituals. Therefore, Halban recalls the opinion of the German theologian Hans von Schubert, who saw in the adoption of Christianity by the Germans a "passage, but not a conversion", while stating that "only partially it had something to do with religion" (Przedhitlerowskie..., 2018: 180). In conclusion, Halban emphasizes that since the $18^{\text {th }}$ century, the contribution of German authors to the creation of a universalist culture and to the implementation of such a worldview on German soil was extremely significant, it was in fact an "export commodity, which enjoyed limited popularity in the country" (Przedhitlerowskie..., 2018: 186).

Suchodolski's text and Halban's texts, despite the passage of time, from the perspective of a researcher interested in the interaction between religion and politics, still constitute a valuable source of information on the processes described in them. Suchodolski developed in Dusza niemiecka a comprehensive outline of the worldview dominating in German society, which is expressed in successive forms revealed in the field of German political and philosophical thought. Halban, in turn, described the multiplicity and power of influence of particular religious and philosophical groups in the general life of German society.

Bogumił and Olgierd Grott point out in their introduction that, unlike in Germany, the openly proclaimed racism was sporadic among Polish political groups, and according to the teaching of the Catholic Church it was rejected as a materialistic view. Religion, being a kind of normative system, shaped the beliefs of its followers by limiting significantly negative attitudes. The whole publication is aimed at indicating the differences in the axiological layer between the representatives of the described German groups, post-exposure Europe, and Catholic societies of Poland or Italy.

Grzegorz Kucharczyk referred to the assumptions presented in Przedhitlerowskie korzenie nazizmu, especially by Suchodolski, in his journalistic article entitled Niemcy nas 
naucza (Eng. Germans will teach us). Referring to the historical policy of Germany and the question of possible reparations from the German state, he emphasizes the fundamental role of Kantian idealism for the "imperialism in relation to reality" characteristic of the next generations of Germans taking the form of seemingly universalistic ideas (Kucharczyk, 2019: 66-67).

The issue, despite the passage of time, is still related to the current situation of further weakening of the social role of Christian churches, or the noticeable rebirth of neopaganism. It is not a matter of making hasty accusations against specific circles, but of understanding the process described in political axiology, because, as the example of Olgierd Grott's book cited above shows, these issues are much more important than inspirations in the sphere of symbols or names of political groups.

\section{Bibliography}

Grott O. (2007), Faszyści i narodowi socjaliści w Polsce, Kraków.

Kucharczyk C. (2019), Niemcy nas naucza, "Do Rzeczy”, No. 14(317), pp. 66-67.

Przedhitlerowskie korzenie nazizmu, czyli dusza niemiecka $w$ świetle religioznawstwa i filozofii (2018), edit. B. Grott, O. Grott, Warszawa. 